inseparable. Educational methods are now demanding to an increasing extent the use of illustrative examples and opportunities for seeing things and for studying processes and their products. The museum, Dr. Allan maintains, is the obvious solution to the problem, and it is the aim of his lecture to indicate how museums can play their part in the educational scheme. A museum must first of all select and define its field. It should then portray the essential activities of man and his environment within the selected region. The need for imagination and understanding to secure an attractive display is stressed. It is also important to decide upon the type of user which it is hoped to attract, and then frame the programme and performance accordingly. Museums have a unique part to play in education, meeting the needs of both formal and informal instruction, of youth and age, of the people at home and the visitor from overseas.

\section{Iraq Natural History Museum, Baghdad}

THE first report of any newly established institution is of interest, for it usually defines policy and to a great extent indicates status. The report of the Iraq Natural History Musoum, Baghdad, for 1946-49 (pp. 58 ; Baghdad : Government Press, 1950) covers the first three formative years and describes the inception, administration and exhibits. Opened on May 2, 1946, by H.R.H. the Regent of Iraq, the establishment of the Museum indicated a real desire by the responsible authorities for a place where the principles of natural science could be exhibited to the public and scientific research of an advanced character be pursued. The Museum is under the Ministry of Education, and its administration is directly linked with the dean of the.Higher Teachers' College in Baghdad. The Museum consists of three main sections-zoology, botany and geology-and the exhibits are of a regional character. The economic and practical aspects of the oil industry are fully illustrated. An appeal for outside help in building up a reference library and collections is made in the report, which is printed in Iraqi as well as English.

\section{Planning a Visual Education Policy}

THE National Committee for Visual Aids in Education was formed to co-ordinate the work of individual teachers and of local authorities in developing visual aids on a national scale. During 1948, striking and significant progress was made in the development of visual aids in schools and colleges throughout Great Britain, and the question now is not whether to use the film and other visual aids in the classroom but rather how to use them. Throughout 1948 the National Committee was engaged in developing a policy for the growth of visual aids in education and in creating the machinery required to enable local authorities to develop in their areas the potentialities of visual aids as part of the teacher's stock-in-trade in the classroom. The formulation of this policy has involved investigations into the establishment of a suitable procedure for determination of material for production; the choice, training and secondment of expert teacher advisers to work in collaboration with film directors ; the appropriate experimental scales of apparatus for different types of schools in various localities; the evaluation of the suitability of projectors on the market for use in schools and colleges; the possibility of the establishment of national, regional and local visual aid libraries; problems concerned with the carrying out of basic experiment and research on education by visual means; and the establishment of a marketing agency for the sale, servicing and distribution of visual aids.

\section{Visual Aids and Wool}

IN a lecture to the London Schools' Film Society on March 6, Mr. P. A. Wells, director of education to the International Wool Secretariat, described the use of visual aids by his organisation. The International Wool Secretariat was set up by the Statutory Wool Boards of Australia, Now Zealand and South Africa in 1937 to further the uses and use. fulness of wool, and its Department of Education seeks to make its work more widely known. For this purpose the Department has built up a film library of some fifty films ranging from the historical to the technical ; two of these films were produced by the Secretariat. There are also eight film strips on similar subjects which, because of the greater flexibility they afford to the teacher in his choice of material, are more widely used by the Secretariat's lecturing staff in talks in schools and other institutions. The Department of Education has also produced a number of wall sheets, a photograph library and collections of samples of wool in various stages of processing:

\section{Science in Adult Education}

ReFerRING to the work on "Science for Farmers" (Nature, 165,342 ; 1950), Mr. A. Champion, warden and resident tutor in Pilgrim College, Fydell House, Boston, Lincs, writes that similar work is being pioneered in the Holland Division of Lincolnshire by the Extra-Mural Department of the University of Nottingham, based on the University's Adult Education Centre, Pilgrim College, Boston, now in its third full year. A popular course of ten meetings on "Natural History" was launched last autumn, touching on aspects of bird and insect migration, plant and animal ecology, and plant life. A similar course ran concurrently at Spalding. Quite vigorous interest was aroused in both places. At Boston, students are approaching plant and animal ecology based on a survey of a local lake, and supplemented by work on bird behaviour at the Lincolnshire Naturalists' Association's bird observatory at Gibraltar Point, near Skegness. At Spalding the course is being related to agriculture, and deals mainly with plant structure and an ecological study of weeds on local fields. Some observation of reclaimed land is also being undertaken. Both courses have attracted keen bodies of students whose enthusiasm, especially in tackling laboratory practical work with improvised apparatus, is a real reward to their tutors. The success of the course at Boston has stimulated members of other classes in the College to seek some instruction in science, and considerable clamour has been raised for an introductory course on geology, which has now been arranged for the summer. The student body in all these courses is widely mixed: some are farmers or directly connected with agriculture, some are school teachers, but the majority have come from general interest only.

\section{Medical Safeguards against $X$-Rays}

HandBook 41 of the United States National Bureau of Standards, entitled "Medical X-ray Protection up to Two Million Volts" (pp. 43; Washington, D.C. : Gov. Printing Office, 1949; 15 cents), supersedes Handbook 20, which was last revised in 1936. The increasing use of high-energy X-rays in 